Research Article

\title{
Lead acetate toxicity on glucose level and liver enzymes ameliorated by camel's milk in wistar albino rat
}

\author{
Marwan M. Draid ${ }^{1}$, Mujahed O. Bushwereb ${ }^{2}$, Shadia G. Ramadan ${ }^{1}$
}

${ }^{1}$ Department of Pharmacology,

Toxicology and Forensic,

${ }^{2}$ Department of Physiology,

Biochemistry and Animal

Nutrition Medicine, University

of Tripoli-13662, Tripoli, Libya

Received: 03 April 2016

Accepted: 07 May 2016

*Correspondence to:

Dr. Marwan M. Draid,

Email: marwan8972

@yahoo.com

Copyright: (C) the author(s), publisher and licensee Medip Academy. This is an openaccess article distributed under the terms of the Creative Commons Attribution NonCommercial License, which permits unrestricted noncommercial use, distribution, and reproduction in any medium, provided the original work is properly cited.

\begin{abstract}
Background: The present work was conducted to investigate the effects of lead acetate intoxication on glucose and liver functions in albino rats, and the possible effectiveness of using camel milk to protect against lead induced toxicity.

Methods: Eighteen male albino rats were divided into three groups of six, the first was a control group, the second received orally lead acetate in water as ( $2 \mathrm{ml}$ saline containing $5 \mathrm{mg} / \mathrm{kg}$ body weight of lead acetate) and the third received the same lead acetate dose and supplemented with $2 \mathrm{ml}$ of camel milk, the experiment lasted for three weeks.

Results: The results indicated that exposure of animals to lead acetate caused a significant increase $(\mathrm{p}<0.05)$ in the activities of aspartate aminotransferase (AST) and decrease $(\mathrm{p}<0.05)$ in the alanine aminotransferase (ALT) compared with control group. Treatment with camel milk seemed to offer a marked improvement of the blood glucose parameter and the liver enzymes compared with lead acetate group. The parameters were reversed towards the normal values significantly.

Conclusions: The ability of camel milk to reduce lead toxicity may relate to its antioxidant actions or enhancing, the metal chelating action. In conclusion, Supplementation of daily diets with camel milk may be recommended to improve the body in case of lead contamination.
\end{abstract}

Keywords: Lead acetate, Camel milk, Blood glucose, Liver enzymes

\section{INTRODUCTION}

Lead $(\mathrm{Pb})$ as heavy post-transition metal has been commonly used for thousands of years because it is widespread, easy to extract and easy to work with. It is highly malleable and ductile as well as easy to smelt. Metallic lead beads dating back to 6400 B.C. ${ }^{1}$ Lead (Pb) had modest early uses in ancient medicines and cosmetics. Today, it has industrial uses in, for example, building materials, lead-acid batteries, bullets, shot, paints, and gasoline. Also, lead has many agricultural uses. ${ }^{2}$ The most bioavailable form of lead, lead acetate, is found in some eye makeup, lipstick and hair dyes. ${ }^{3}$
Human exposure to lead is from numerous sources including air, food, dust, soil and water. ${ }^{4}$ The highest concentrations of lead were recorded and found in the liver and kidney, and lower concentrations recorded in muscle and lung. A lead concentration of $2.2 \mathrm{mg} / \mathrm{kg}$ was found in horse liver. ${ }^{5}$

Gastrointestinal (GI) absorption varies depending on nutritional status and age. Iron is believed to impair lead uptake in the gut, while iron deficiency is associated with increased blood lead concentrations in children. ${ }^{6}$ Calcium supplementation studies demonstrate that increased dietary calcium in animals, infants, and children result in consistent decreases in the absorption of lead. ${ }^{7}$ 
Increased intakes of magnesium, phosphate, alcohol, and dietary fat have also been shown to decrease gastrointestinal absorption of lead. ${ }^{8}$ In mammalian livers, glutathione has an important role in detoxification of heavy metals as well as electrophilic organo-compounds. ${ }^{9}$ Several studies have shown that the effect of inorganic lead on hepatic glutathione content varied from case to case; a single injection of lead decreased glutathione content, whereas long-term lead exposure increased hepatic glutathione content. ${ }^{10,11}$ In many cases, research carried out in the former Soviet Union showed that camel's milk was superior to mare's milk, which in turn was superior to milk of other animals. Mare's milk is being exploited at present in Germany for medicinal purposes. Historically, camel milk has been used for a number of medical problems. ${ }^{12}$ The unique and special characteristics of camel milk are seen in it is often used to counter diseases such as diabetes and hepatic and microbial infections, in addition to the reported improvement effects in blood and renal and hepatic functions. ${ }^{13-16}$ Camel milk proteins has many characteristics similar to insulin. ${ }^{17}$ In Asia, it was shown that camel's milk had a beneficial action on chronic liver patients and An Indian study reported hypoglycaemic effect of camel milk on diabetic rats. ${ }^{18,19}$ Our study aims to identify if the harmful effects of lead acetate on glucose and liver function indicators of Wister albino rat can be reduced using camel milk.

\section{METHODS}

\section{Animals}

This study was approval by Libyan academy ethics review committee. Eighteen male wister albino rats (150$250 \mathrm{~g}$ body weight) were obtained from biotechnology research center (BTRC), Twisha, Tripoli, Libya, and housed in the national medical research center (NMRC), Al Zawiyah, Libya. The rats were kept in a controlled environment of $50-60 \%$ humidity at $25{ }^{\circ} \mathrm{C}$ with 12 hours light/dark period, and were treated gently. A standard rodent pellets consisting of a mixture of protein, fat, fibre, and ash were used to feed the rats. Diet and water supply were ad libitum. The rats were randomly distributed into three groups, each of six animals; the experiment was carried out for three weeks.

\section{Camel milk}

Camel's milk samples were collected in early morning daily from camel's farm in Tajoura area (east of Tripoli city). Full milk is milked from camels by hand milking as normally practiced by the farmers. Collected milk in bottles kept in cool boxes until transported to the laboratory.

\section{Lead acetate}

The lead acetate (analytical grade purity) was purchased from Sigma-Aldrich (St. Louis, MO, USA).

\section{Experimental design groups}

Control group: was under same room conditions, drank only water ad libitium. Lead acetate group: Given a daily $2 \mathrm{~mL}$ dose of a normal saline contains $5 \mathrm{mg} / \mathrm{kg}$ body weight of lead acetate orally. Lead acetate+camel milk group: Given a daily $2 \mathrm{ml}$ dose of camel milk contains 5 $\mathrm{mg} / \mathrm{kg}$ body weight of lead acetate orally.

On day 21, rats were anaesthetized with ketamine hydrochloride $(10 \mathrm{mg} / \mathrm{Kg})$. Blood samples were collected through open chest method, rats been euthanized immediately after blood collection. Serum collection plastic tubes (Additive clot activator and silicone coated interior, $10.0 \mathrm{ml}$ volume) were used, these tubes supplied from BD Vacutainer ${ }^{\circ}$. The resultant serum was collected and stored at $-80{ }^{\circ} \mathrm{C}$ until analysed. Glucose, ALP, AST, and ALT were determined using a Reflotron plus analyzer (Roche Diagnostic Ltd, Germany).

The data are expressed as mean \pm standard error $(n=6)$, $\mathrm{n}$ represents the number of wister albino rat. Statistical analysis was performed student's t-test was used after, 20 and $\mathrm{P}<0.05$ were considered statistically significant.

\section{RESULTS}

The daily observations showed no external or behaviour changes recorded during experiment with all groups eating and drinking similar amounts.

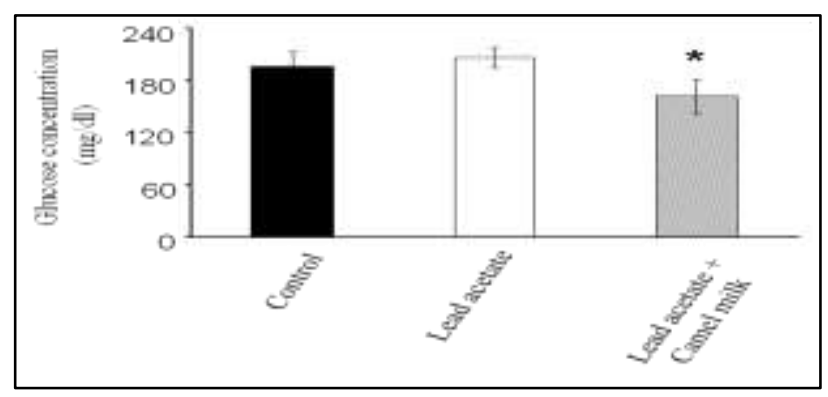

Figure 1: The effect of lead acetate and lead acetate concurrent with camel milk on glucose concentration. *Significant at $(\mathbf{p}<0.05)$, compared with the lead acetate group.

Contaminated with lead acetate increased the activity of ALP 310.15 and significantly $(p<0.05)$ of AST 279.9, while it decreased significantly $(p<0.05)$ the level of ALT 78.0 in comparison to the control group. On the other hand, the blood glucose was slightly increased for lead acetate group in comparison to the control 206.3 and 195.7 respectively. The activities of AST and ALT were decreased significantly $(\mathrm{p}<0.05)$ with the group taking camel milk (136 and 37 respectively) in comparison to lead acetate group (279.9 and 78.6 respectively). Although, the activity of ALP was decreased with the group taking camel milk but did not show statistical difference. The results shows as well that the inclusion of 
camel milk decreased significantly $(p<0.05)$ the blood glucose compare with lead acetate group 162 and 206.3 respectively.

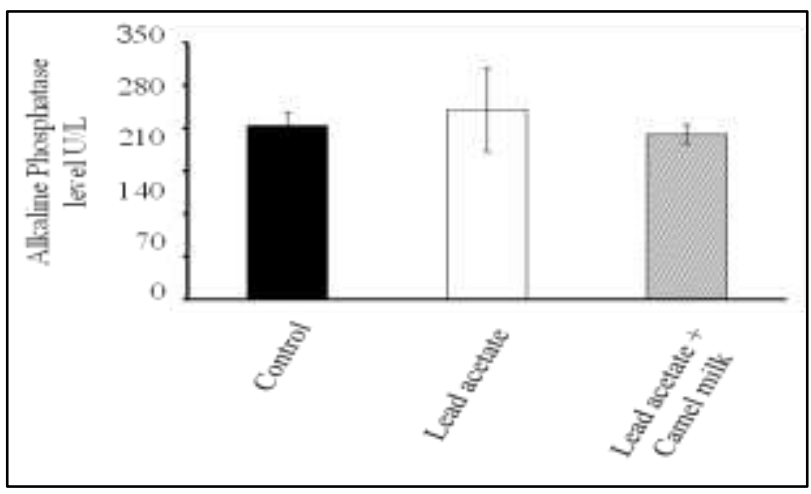

Figure 2: The effect of lead acetate and lead acetate concurrent with camel milk on alkaline phosphatase level (ALP).

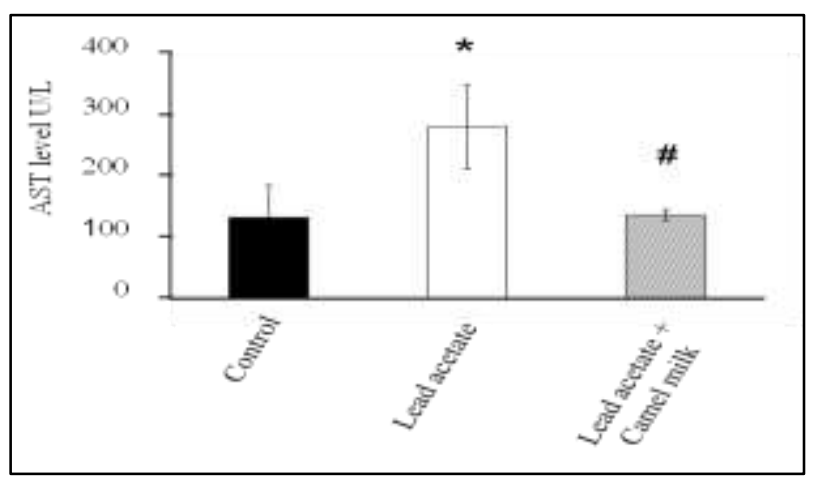

Figure 3: The effect of lead acetate and lead acetate concurrent with camel milk on Aspartate Aminotransferase level (AST). * Significant at (p<0.05), compared with the control group. Significant at $(p<0.05)$, compared with the lead acetate group.

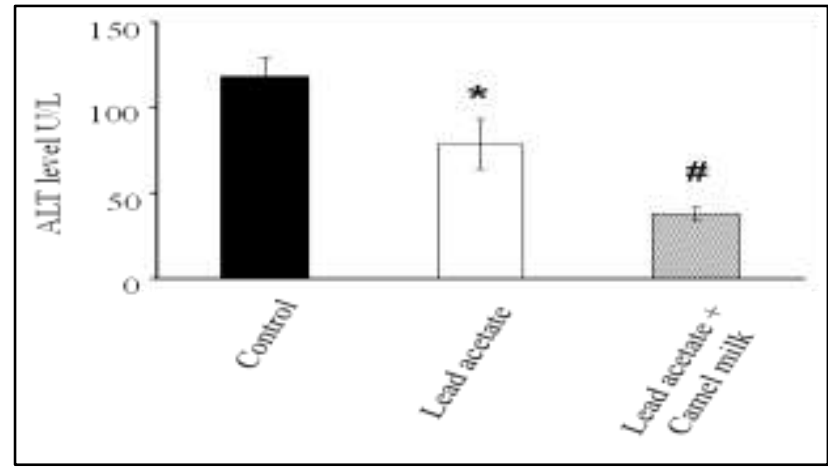

Figure 4: The effect of lead acetate and lead acetate concurrent with camel milk on Aspartate

Aminotransferase level (ALT). * Significant at $(\mathbf{p}<0.05)$, compared with the control group. ${ }^{\#}$

Significant at $(\mathbf{p}<0.05)$, compared with the lead acetate group.

\section{DISCUSSION}

Lead is one of the most toxic materials encountered in everyday life and it is capable of causing numerous acute and chronic illnesses. It affects each and every organ and system in the body. ${ }^{21}$ Neurotoxicity from lead exposure is of concern especially because lead at even very low concentrations can have profoundly detrimental neurological effects. ${ }^{22}$

The present study was to investigate the impact of the combined administration of camel milk with lead-induced toxicities on wister albino rats. All treated groups of rat's revealed normal without any visible toxic signs or any clinical symptoms throughout the experimental period. Lead impacts many organ systems, but this study focused only on glucose level and liver enzymes activities. Occupational and environmental exposure to lead, a toxic metal pollutant, is of global concern. Lead has been found in drinking water. It can come from plumbing and fixture that may be made of lead. ${ }^{23}$ Absorbed lead is stored in soft tissues mainly the liver tissues. ${ }^{24}$ The liver, via the portal vein, is the first organ exposed to internally absorbed nutrients.

Table 1: Effects of exposure to lead acetate, and lead acetate+camel milk on serum glucose, alkaline phosphate (ALP), aspartate aminotransferase level (AST), and alanine aminotransferase (ALT) (mean \pm standard deviation within eighteen male Wister albino rats $(n=6$ per group).

\begin{tabular}{|lccc|} 
Parameter & Control mean \pm SE & Lead acetate mean \pm SE & Lead acetate+camel milk mean \pm SE \\
\hline Glucose $(\mathrm{mg} / \mathrm{dl})$ & $195.7 \pm 16.9$ & $206.3 \pm 12.0$ & $162.0 \pm 29.0^{*}$ \\
\hline ALP $(\mathrm{U} / \mathrm{l})$ & $284.3 \pm 22.3$ & $310.15 \pm 68.4$ & $270.1 \pm 15.9$ \\
\hline AST $(\mathrm{U} / \mathrm{l})$ & $131.65 \pm 52.8$ & $279.9 \pm 69.1^{*}$ & $136.07 \pm 8.9^{*}$ \\
\hline ALT $(\mathrm{U} / \mathrm{l})$ & $118.3 \pm 19.6$ & $78.6 \pm 18.8^{*}$ & $37.93 \pm 3.63^{*}$ \\
\hline
\end{tabular}

*Mean value was significantly different to that at control and lead acetate group $(\mathrm{P}<0.05), \mathrm{SE}=$ standard error; \# Mean value was significantly different to that at lead acetate and lead acetate+camel milk group $(\mathrm{P}<0.05), \mathrm{SE}=$ standard error. 
Our study showed that lead acetate elevated the blood glucose level insignificantly, this comes in agreement with the results observed by AL-Humaid. ${ }^{25}$ Similarly, present findings are also support the findings of Nabil, who have suggested that the elevations in blood levels may be due to increases in the rate of glucose transport from the tissues to blood or decreased rate removal of glucose from the blood to tissues. ${ }^{26}$ The traditional believe in the Middle East is that regular consumption of camel milk helps in prevention and control of diabetes, it has also been reported that camel milk can have such properties. ${ }^{27-29}$ Such beneficial effects of camel milk might be due to presence of insulin in the milk or some other substances able to modulate glucose level. Our results agree with previous studies that camel milk had a healthy effect by reducing the level of blood glucose that has been elevated by lead acetate exposure. And this effect due to it contains higher level of insulin than milk from other animals but to be effective it would have to be absorbed directly in the buccal cavity or completely proteolytically protected during passage through stomach and absorbed in the intestine. ${ }^{30}$

Activity of AST increases in serum following tissue damage. $^{25}$ AST is present in both mitochondria and cytosol of liver cells, while ALT is found in cytosol only. However, it is worthwhile to note that ALT is more commonly used for screening of liver problems, as the AST level may also be increased as a result of deficiencies or diseases in other bodyorgans. ${ }^{31}$ Administering of Lead acetate to rats showed a significant increase of AST in the rat's serum compared with the control group. The high values of these enzymes came in agreement with the finding of Haque who reported that following lead acetate administration significant elevation of AST was observed. ${ }^{32}$ Similarly, Berny also observed significant elevation on AST following lead acetate administration at different doses. ${ }^{33}$ The significantly elevated serum enzymes observed in this study could be as a result of the leakage of this enzyme from damaged tissues, into the blood stream; this is particularly evident in the lead treated group where both AST was significantly increased.

However, adding camel's milk to lead acetate produced a significant decrease in relation to rats received lead acetate only, but the elevated level of enzyme is decreased to near normal level after 21 days treatment with camel's milk indicates that it may offered a sort of protection for hepatocellular membrane. Hamad found that camel milk led to an improvement in activities of alanine aminotransferase and aspartate amino-transferase by 41 and $38 \%$, respectively and this founding is contrast with our founding. ${ }^{34}$ Our results suggest that camel milk is a barrier against lead acetate damage and that camel milk helped to neutralise the liver cell injury by the use of lead acetate on kidney.

Treatment with lead acetate significantly $(\mathrm{p}<0.05)$ decreased hepatic ALT only compared to the controls
(Table 1 and Figure 3). The decrease in the activity of hepatic ALT could be expected to occur associating with the pathology involving necrosis of the liver. ALT level is of value indicating the existence of liver diseases, as this enzyme is present in large quantities in the liver. It decreases in liver tissue when cellular degeneration or destruction occurs in this organ. ${ }^{35}$ Even Abdou observed a significant decrease in liver ALT enzyme in liver extract. $^{36}$ As mention previous that camel milk has the ability to improve to activity of all liver enzyme including ALT. On the other hand, it was reported that oral administration of lead acetate $(100 \mathrm{mg} / \mathrm{kg}$ body weight) to experimental rats decreased significantly the activity of ALT after 4 months of treatment. ${ }^{37}$ A group of researcher concluded that the long-term exposure to low lead concentrations as $(0.025 \% \mathrm{PbAc})$ through drinking water can reduce the level of ALT enzyme. ${ }^{38}$ In conclusion, our findings reveal that camel milk is a barrier against lead acetate damage and that camel milk property helped to neutralise the injury by the exposure of lead acetate on liver.

\section{CONCLUSION}

In conclusion, camel milk seems to ameliorate the blood glucose and the liver functions in wister albino rat exposed to lead toxicity.

\section{ACKNOWLEDGEMENTS}

The authors are thankful to Professor Abdul M. Gabaj, national medical research center, Al Zawiyah-Libya, for generous help by providing us with analysis instrument and technical support.

\section{Funding: No funding sources}

Conflict of interest: None declared

Ethical approval: The study was approved by the Institutional Ethics Committee

\section{REFERENCES}

1. Heskel DL. A model for the adoption of metallurgy in the ancient middle east. Current Anthropology, 1983;24:362-6.

2. Dioka CE, Orisakwe OE, Adenyl FA, Meludu SC. Liver and renal function tests in Artisans occupationally exposed to lead in Mechanic village in Nnewi, Nigeria. Int $\mathrm{J}$ Environ Res Health. 2004; 1:21-5.

3. Hepp NM, Mindak WR and Cheng J. Determination of total lead in lipstick: Development and single lab validation of a microwave-assisted digestion, inductively coupled plasma-mass spectrometric method. J Cosmet Sci. 2009;60:405-14.

4. Herman DS, Geraldine M, Venkatesh T. Case report: evaluation, diagnosis, and treatment of lead poisoning in a patient with occupational lead exposure: a case presentation. J Occup Med Toxicol. 2007;2:7-10. 
5. Farmer AA, Farmer AM. Concentrations of cadmium, lead and zinc in livestock feed and organs around a metal production centre in eastern Kazakhstan. Sci total Environ. 2000;257:53-60.

6. Ziegler EE, Edwards BB, Jensen RL, Mahaffey KR, Fomon SJ. Absorption and retention of lead by infants. Pediatr Res. 1978;12:29-34.

7. Bogden JD, Gertner SB, Christakos S, Kemp FW, Yang Z, Katz SR, et al. Dietary calcium modifies concentrations of lead and other metals and renal calbindin in rats. J Nutr. 1992;122:1351-60.

8. Barltrop D, Meek F. Effect of particle size on lead absorption from the gut. Arch Environ Health. 1979;34:280-5.

9. Ballatori N, Clarkson TW. Biliary secretion of glutathione and glutathione-metal complex. Fundam. Appl. Toxicol. 1985;5:816-31.

10. Dalvi RR, Robbins TJ. Comparative studies on the effect of cadmium, cobalt, lead, and selenium on hepatic microsomal mono oxygenase enzymes and glutathione levels in mice. J Environ Pathol Toxicol. 1978;1:601-7.

11. McGowan C, Donaldson WE. Effect of lead toxicity on the organ concentration of glutathione and glutathione related free amino acids in the chick. Toxicol Lett. 1987;38:265-70

12. Yagil R. Camels and camel milk. Italy: FAO (Food and Agricultural Organization of the UN).

13. Redwan El-RM, Tabll A. Camel lactoferrin markedly inhibits hepatitis $C$ virus genotype 4 infection of human peripheral blood leukocytes. J Immunoassay Immunochem. 2007;28:267-77.

14. Saltanat H, Li H, Xu Y, Wang J, Liu F, Geng XH. The influences of camel milk on the immune response of chronic hepatitis B patients. 2009:25:431-3.

15. Althnaian $\mathrm{T}$, Albokhadaim I, El-Bahr SM. Biochemical and histopathological study in rats intoxicated with carbontetrachloride and treated with camel milk. Springer Plus. 2013;2:57.

16. Sharmanov TS, Zhangabylov AK, Zhaksylykova RD. Mechanism of the therapeutic action of whole mare's and camel's milk in chronic hepatitis. Vopr Pitan. 1982;1:17-23.

17. Beg OU, Von Bahr-Lind Strom H, Zaidi ZH, Jornvall $\mathrm{H}$. Characterristic of camel milk protein rich in prolline identifies a new beta casein fragment. Regulatory Peptides. 1989;15:55-61.

18. Sharmanov TS, Kadyrova RK, Shlygina OE, Zhakslykova RD. Changes in the indicators of radioactive isotopes studies of the liver of patients with chronic hepatitis during treatment with whole camel's milk and mare's milk. Voprsy Pitaniya. 1978;1:9-17.

19. Agrawal RP, Sahani MS, Tuteja FC. Hypoglycemic Activity of Camel Milk in Chemically Pancreatectomized Rats-An Experimental Study. Int J Diabetes Dev Ctries. 2005;25:75-9.

20. Snedecor GW, Cochran GW. Statistical methods. $6^{\text {th }}$ Edition. Ames: Iowa State University Press; 1973.
21. Goyer RA. Lead toxicity: from overt to subclinical to subtle health effects. Environ Health Perspect. 1990;86:177-81.

22. Bellinger DC. Lead, Pediatrics. 2004;113:1016-22.

23. Mudipall A. Lead hepatotoxicity and potential health effects. Indian J Med Res. 2007;126:518-27.

24. Lyn Patrick ND. Lead toxicity part II: The role of free radical damage and the use of antioxidant in the pathology and treatment of lead toxicity (Review) Altern. Med Rev. 2006;11:114-27.

25. Al-Humaid AI, Mousa HM, El-Mergawi RA, AbdelSalam AM. Chemical composition and antioxidant activity of dates and dates-camel-milk mixtures as a protective meal against lipid peroxidation in rats. Am J Food Technol. 2010;5:22-30.

26. Nabil MI, Eweis ES, El-Beltagi HS, Yasmin E. Effect of lead acetate toxicity on experimental male albino rat . Asian Pacific J of Tropical Biomedicine. 2012;2:41-6.

27. Agrawal RP, Dogra R, Mohta N, Tiwari R, Singhal $\mathrm{S}$, Sultania S. Beneficial effect of camel milk in diabetic nephropathy. Acta Biomed. 2009;80:131-4.

28. Agrawal RP, Jain S, Shah S, Chopra A, Agarwal V. Effect of camel milk on glycemic control and insulin requirement in patients with type 1 diabetes: 2-years randomized controlled trial. Eur $\mathrm{J}$ Clin Nutr. 2011;65:1048-52.

29. Mohamad RH, Zekry ZK, Al-Mehdar HA. Camel milk as an adjuvant therapy for the treatment of type 1 diabetes: verification of a traditional ethnomedical practice. J Med Food. 2009;12:461-5.

30. Zagòrski O, Maman A, Yafee A, Meisles A, van Creveld C, Yagil R. Insulin in milk: a comparative study. Int J Anim Sci. 1998;13:241-4.

31. Bujanda L, Hijona E, Larzabal M, Beraza M, Aldazabal P, García-Urkia N, et al. Resveratrol inhibits nonalcoholic fatty liver disease in rats. BMC Gastroenterology. 2008;8:40-8.

32. Haque MM. Effects of calcium carbonate, potassium iodide and zinc sulfate in lead induced toxicities in mice. MS Thesis, Department of Pharmacology, Bangladesh Agricultural University, Mymensingh, Bangladesh; 2005.

33. Berney PJ, Cote LM, Buck WB. Low blood lead concentration associated with various biomarkers in household pets. Am J Vet Res. 1994;55:55-62.

34. Hamad EM, Abdel-Rahim EA, Romeih EA. Beneficial effect of camel milk on liver and kidneys function in diabetic sprague-dawley rats. Int J Dairy Sci. 2011;6:190-7.

35. Hassoun EA, Stohs SJ. Comparative studies on oxidative stress as a mechanism for the fetotoxic of TCDD. endrin and lindane in C57BL/6J and DBA/2J mice. Teratology. 1995;51:186.

36. Abdou HM, Newairy AA. Hepatic and reproductive toxicity of lead in female rats and attenuation by flaxseed lignans. JMRI. 2006;27:295-302.

37. Singh B, Dhawan D, Garg ML, Mangal PC, Chand $B$, Trehan PN. Impact of lead pollution on the status of other trace metals in blood and alterations in 
hepatic functions. Biol Trace Elemen Res. 1994;40:21-9.

38. Allouche L, Hamadouche M, Touabti A, Khennouf S. Effect of long-term exposure to low or moderate lead concentrations on growth, lipid profile and liver function in albino rats. Advan Biol Res. 2011;5:339-47.

Cite this article as: Draid MM, Bushwereb MO, Ramadan SG. Lead acetate toxicity on glucose level and liver enzymes ameliorated by camel's milk in wistar albino rat. Int $\mathrm{J}$ Basic Clin Pharmacol 2016;5:1125-30. 